\title{
Judicial Independence and Party Politics in the Kelsenian Constitutional Courts: The Case of Portugal
}

Sofia Amaral-Garcia

Nuno M. Garoupa

Texas A\&M University School of Law, ngaroup@gmu.edu

Veronica Grembi

Follow this and additional works at: https://scholarship.law.tamu.edu/facscholar

Part of the Comparative and Foreign Law Commons, Law and Politics Commons, and the Law and Society Commons

\section{Recommended Citation}

Sofia Amaral-Garcia, Nuno M. Garoupa \& Veronica Grembi, Judicial Independence and Party Politics in the Kelsenian Constitutional Courts: The Case of Portugal, 6 J. Empirical Legal Stud. 381 (2009).

Available at: https://scholarship.law.tamu.edu/facscholar/622

This Article is brought to you for free and open access by Texas A\&M Law Scholarship. It has been accepted for inclusion in Faculty Scholarship by an authorized administrator of Texas A\&M Law Scholarship. For more information, please contact aretteen@law.tamu.edu. 


\title{
Judicial Independence and Party Politics in the Kelsenian Constitutional Courts: The Case of Portugal
}

\author{
Sofia Amaral-Garcia, Nuno Garoupa, and Veronica Grembi*
}

\begin{abstract}
In this article we test to what extent Kelsenian-type constitutional judges are independent from political parties by studying the Portuguese constitutional court. The results yield three main conclusions. First, constitutional judges in Portugal are quite sensitive to their political affiliations and their political party's presence in government when voting. Second, peer pressure is very relevant. Third, the 1997 reform enacted to increase judicial independence has had no robust statistically significant effect.
\end{abstract}

\section{INTRODUCTION}

The economic analysis of constitutional courts is receiving increasing attention due to the recognition that the appropriate design of judicial review plays an important role in assessing constitutional frameworks. ${ }^{1}$ Conformity with the constitution is a central issue in assessing the various dimensions of political and legal reform, particularly because constitutional adjudication

\footnotetext{
*Address correspondence to Nuno Garoupa, UIUC College of Law, 504 E. Pennsylvania Ave., Champaign, IL 61820; email: ngaroupa@law.uiuc.edu. Amaral-Garcia is an EDLE Candidate, Università di Bologna; Garoupa is at the UIUC College of Law, IMDEA (Madrid) and CEPR (London); Grembi is at the Università Cattolica del Sacro Cuore (Milan).

We are grateful to one anonymous referee, the editor, Ted Eisenberg, and to Tom Ginsburg, José Maria Labeaga, Pedro Magalhães, António Morgado, Pedro Pita Barros, Stefan Voigt, and the participants at ISNIE 2007 and SIDE 2007 meetings and seminars in Vigo and Central European University for useful comments and suggestions. Sofia Amaral-Garcia acknowledges financial support by FCT, POCTI/ECO/44146/2002, and Nuno Garoupa acknowledges financial support by FCT, PPCDT/JUR/55752/2006. We are also grateful to Yeny C. Estrada for reviewing the article. The usual disclaimers apply.

'A good introduction is provided by Ginsburg (2002).

(C) 2009, Copyright the Authors Journal compilation (C 2009, Cornell Law School and Wiley Periodicals, Inc.
} 
should respond to long-run interests and prevent politicians from maximizing short-run opportunities.

Politicians who have drafted a constitution determine the role of the constitutional court. Therefore, it is likely that the design aims to protect their interests. Hence, the choice of centralization, standing, size of the court, the appointment mechanism employed, and the authority to engage in abstract versus concrete review must respond to the potential or expected problems faced by future drafters. We cannot understand the role of a given constitutional court without paying attention to the political process underlying the production of the constitution. ${ }^{2}$

In general, courts can be seen either as pure gatekeepers of the law or as innovative lawmakers who engage in what is sometimes called judicial activism. Constitutional courts are no exception. In the U.S. model, constitutional courts provide constitutional interpretations that effectively develop new law in order to adjust to changes in the community. Judicial boldness might create serious conflicts with politicians but little pressure exists for substantive constitutional reform from society in general. In the Continental model, constitutional courts are intended to be more conservative in interpreting constitutions and are restrained from embracing active law making. ${ }^{3}$ Even though there are minor conflicts with politicians, there might be serious pressure for frequent substantive constitutional reform. In both models, the politics of judicial review plays a very important role. ${ }^{4}$

Judicial decision making in a constitutional court is in part the result of personal attributes, ${ }^{5}$ attitudes (including policy preferences), peer pressure, and intracourt interaction (a natural pressure for consensus and court reputation; a common objective to achieve supremacy of the constitutional court), and party politics (loyalty to the appointer) within a given constitu-

\footnotetext{
'See, among others, Lutz (1994), Cooter (1992), and Ramos (2006).

${ }^{3}$ For a discussion of judicial activism by a Continental constitutional court, see Kommers (1994) on the German case. There is also evidence of judicial activism by the French constitutional court since the early 1980s. See, for example, Davis (1986) and Bell (1988).

${ }^{4}$ For a general discussion, see Friedman (2005) and McCubbins and Rodriguez (2006).

${ }^{5}$ For judicial preferences, see Easterbrook (1990), Posner (1993, 2005), Baum (1994), Schauer (2000), and Guthrie et al. (forthcoming).
} 
tional and doctrinal environment. ${ }^{6}$ Hence, for example, the observation that conflicts between constitutional courts and the parliament, or the government, occasionally exist might be explained by two factors. On one hand, conflict may exist because constitutional judges are appointed, and therefore heavily influenced by political parties (judicial independence becomes an issue); on the other hand, conflict may be reduced as a natural consequence of the more passive role that a gatekeeper approach imposes (e.g., judges are interested in maintaining a certain status quo that does not damage the prestige of the court). Furthermore, conformity between constitutional judges and party interests can be explained by two different reasons. First, given the political choice of constitutional judges, they exhibit the same preferences as the party that selects them. Second, when the constitutional judges do not have life-time appointments, they might want to maintain good relations with the party that selected them in the hope of securing future appointments to the court or elsewhere (regardless of whether the terms are renewable or not). Both reasons suggest that judges have a political bias incentive and are not fully independent.

Therefore, the process of recruitment and appointment of judges is a major variable in the design of constitutional courts. Overly party-oriented mechanisms are especially bad for independent judicial review, but are quite likely to smooth conflicts with other bodies of governance. Cooperative mechanisms that require a supermajority deliver consensual constitutional courts that are more deliberative than active lawmakers. ${ }^{8}$

These issues are amenable to empirical analysis. The proper response to the many identified tradeoffs cannot be convincingly provided without an adequate empirical assessment. ${ }^{9}$ Although the U.S. Supreme Court has been the focus of much attention by legal scholars, ${ }^{10}$ empirical debate about other

\footnotetext{
${ }^{6}$ For example, see the models developed by George and Epstein (1992) or Lax and Cameron (2007).

${ }^{\bar{T}}$ Theories of judicial independence include Landes and Posner (1975), Epstein (1990), and Ramseyer (1994).

${ }^{8}$ See Ginsburg (2003) and references therein.

${ }^{9}$ For example, while the political science literature finds significant ideological influence in judicial decisions (see Friedman 2005), other authors do not find that characteristics of judges offer a good prediction of outcomes in most cases. See Ashenfelter et al. (1995).

${ }^{10}$ See, for example, Harvey and Friedman (2006) and references therein.
} 
constitutional courts is almost nonexistent, with notable exceptions. ${ }^{11}$ This article extends the empirics of testing the determinants of judicial independence by analyzing Portuguese constitutional cases.

\section{The Case of Portugal}

This article uses the Portuguese judiciary as an example to test the extent to which Kelsenian-type constitutional judges are dependent on their political parties in a supermajority appointment system. ${ }^{12}$ As in other countries (e.g., Germany and Spain), a de facto quota system exists that allocates judicial appointments to the four major parties. ${ }^{13}$ Therefore, the Portuguese constitutional court broadly reflects parliamentary preferences without major bias against either of the two main blocks (left or right). Obviously, the stability of the Portuguese constitutional court very much relies on the stability of party politics. Unsurprisingly, deadlock occurs when there is a temporal discrepancy between the majority of the parliament and the majority of the court.

Portugal has a very long and detailed constitution (currently 296 articles), and thus empowers the constitutional court to intervene frequently in policy making. However, serious conflicts between the constitutional court and the parliament, or the government, leading to a political deadlock are not very frequent and are mainly caused by the court adhering to a literal

\footnotetext{
"On Japan and the Japanese Supreme Court, see Ramseyer and Rasmusen (2003, 2006). On Italy, see Fiorino et al. (2007).

${ }^{12}$ See Kelsen (1942). The Kelsenian model proposes a constitutional court to be a "negative legislator" since it stops legislation from entering the legal system, hence sharing legislative power with the legislator. However, most constitutional courts go beyond the original Kelsenian model by exercising more power than a mere "negative legislator."

${ }^{13}$ Currently, there are five main parties: PS (Partido Socialista, socialists), PSD (Partido Social Democrata, conservative), PCP (Partido Comunista Português, communists), CDS (Centro Democrático Social, Christian Democrats), and BE (Bloco de Esquerda, extreme left). The socialists were in power from 1983 to 1985 (grand coalition with PSD), 1995 to 2002 (minority government), and since 2005 (with an overall majority); the conservatives were in power from 1983 up to 1985 with the socialists and then from 1985 to 1995 (alone with an overall majority); a coalition between conservatives and Christian Democrats has governed from 2002 to 2005 . For background information, see Goldey (1983); for updated reviews, see Magone (2005) and Costa Lobo (2006).
} 
interpretation of the constitution. The Portuguese Constitution dates from 1976 and has been reformed seven times since then. The constitutional court was created in 1982, after the first constitutional reform. ${ }^{14}$ Given the original profound leftist ideological bias of the constitution, serious conflicts are more likely to occur when a right-wing majority dominates the parliament. ${ }^{15}$ Constitutional judicial review is centralized (concentrated in the constitutional court) and decentralized (diffused across the judicial courts). It is a hybrid system that some authors have described as being more similar to the U.S. than the Continental model. ${ }^{16}$

Portugal has a semi-presidential system that resembles that of France. It has a directly elected president who can be elected only twice consecutively for a fixed term of five years. The prime minister is appointed by the president and must have the confidence of the parliament. The members of parliament are elected for a fixed term of four years. The president can dismiss the government and dissolve the parliament, and thereby call for an early election, under certain circumstances. Neither the president nor the government as a whole has appointing power with regard to the constitutional court; only the parliament and, to a more limited extent, the elected judges of the court, have that power. ${ }^{17}$

Legislation can be enacted by the parliament, or by the government, depending on a complex balance between executive and legislative powers. In any case, legislation must be approved by the president, who can veto it or

\footnotetext{
${ }^{14}$ Between 1976 and 1982 , there was a constitutional standing committee within the Council of Revolution (the guardians of the military coup that abolished the conservative dictatorship in 1974). This council was abolished in 1982, marking the definitive consolidation of democracy. Only the communists (PCP) and their allies were against this change.

${ }^{15}$ Only the Christian Democrats voted against the constitution in 1976 , although most of the votes of article by article were unanimous. There was no constitutional referendum.

${ }^{16}$ See Amaral (2005) (in Portuguese). The explanation seems to rely on the influence of the Brazilian Constitution (this one heavily influenced by the U.S. model) on the 1911 Portuguese Constitution. Decentralized constitutional review is exercised by regular courts in concrete and specific cases. Decisions concerning the concrete unconstitutionality of laws in the context of a specific case are subject to appeal to the constitutional court. Those are the majority of the cases heard by the constitutional court.

${ }^{17}$ The exclusion of the president from the appointment procedure for the constitutional judges (but, e.g., not from the high judicial council) has been a matter of controversy and is explained by the political situation in 1982 when the then president lacked the confidence of the three main parties, conservatives (PSD), socialists (PS), and Christian Democrats (CDS).
} 
require judicial review by the constitutional court. In practice, review of legislation, requested by the president, is more likely when the government and the majority in the parliament are from a different political party than that of the president. The presidency was dominated by the left from 1983 to 2006, whereas right-wing parliamentary majorities were in office from 1985 to 1995 and from 2002 to 2005.

There are 13 constitutional judges. Ten of the judges are elected by the parliament, which requires a two-thirds majority (we will refer to them as elected judges), and the remaining three are chosen by the elected judges (we will refer to them as appointed judges). Six of them are necessarily career magistrates. ${ }^{18}$ The elected judges tend to reflect the political composition of the parliament at the time of the election and, in practice, the elected judges are extracted from a unique list of names negotiated by the parliamentary leadership of the main parties. Judges are elected for nonrenewable terms of nine years (before 1997, the mandate was for six years and renewable for a second period in office) and they enjoy all the standard privileges of career magistrates. There have been five courts ${ }^{19}$ although we look at only four $\left(1983-1989,1989-1998,{ }^{20} 1998-2003,{ }^{21} 2003-2007^{22}\right)$ since the new one was recently inaugurated.

The Portuguese constitutional court exercises preventive, concrete, and abstract methods of constitutional review. ${ }^{23}$ In this article, we concen-

\footnotetext{
${ }^{18}$ Every member of the court must hold a law degree, unlike, for example, the French constitutional court.

${ }^{19}$ The duration of each court is defined by the parliamentary election of the majority of the judges, and a new president and vice-president of the court. In theory, the terms should have been 1983-1989, 1989-1995, 1998-2007, and 2003-2012, but resignations, early retirements, and sudden deaths have precipitated new elections for the court

${ }^{20}$ Political deadlock resulted in the third court being inaugurated three years later than it should have been.

${ }^{21}$ The first court to which the 1997 change of rules concerning duration and renewal of mandate apply.

${ }^{22}$ The inauguration of the fourth court was precipitated by the resignation or retirement of five judges from the third court in 2002 and early 2003.

${ }^{23}$ There is another peculiar form: unconstitutionality by omission. The president can ask the constitutional court to signal omission in certain legislative areas necessary to implement constitutional rights. They do not bind other branches of government. Obviously they are very rare.
} 
trate on the method of preventive review because this method is more related to party politics and usually receives a lot of media attention. ${ }^{24}$ Preventive review occurs before legislation is enacted and on request or referral by the president; in the case of supermajority laws, the prime minister or one-fifth of the parliament can also request preventive review. ${ }^{25}$ Given the political importance of preventive constitutional review, these decisions are the ones in which we anticipate a higher degree of party politics. We do not expect party alignment to occur all the time, since judges want to maintain a reasonable reputation for independence. We should note that the vast majority of the work by the constitutional court is on concrete judicial review. ${ }^{26}$ The constitutional court has very little control over its docket, but the right of rejecting a plea for lack of merit in the context of concrete judicial review has been exercised on several occasions. ${ }^{27}$

The constitutional court has the power to declare laws unconstitutional and immediately void. In the case of preventive review, the president must then veto and send legislation back to the government or the parliament to be eventually modified or purged. There is the alternative of a constitutional amendment later in time, or the approval of the same law by a qualified majority (both require a two-thirds majority). However, parties have been quite compliant and usually acknowledge the court decisions without engaging in an open conflict. Hence, with respect to many important legislative decisions, the court imposes its influence via new legislation.

Constitutional judges are overwhelmingly law professors, professional politicians with a law degree, or high-ranking career magistrates. At least six career judges are present in the court per term. At least 10 constitutional judges, the elected judges, are easily identified with a political party for each term in office. However, an agreement that apparently exists between the main parties that establishes six judges for each block. Within each ideological

\footnotetext{
${ }^{24}$ Our interpretation is consistent with Vanberg (1998) and de Araújo and Magalhães (2000) (in Portuguese).

${ }^{25}$ In our data set, we only have preventive review requested by the president.

${ }^{26}$ More than 85 percent of the cases heard by the constiutional court in the period $1983-2007$. Concrete judicial review is exercised by judicial courts while hearing specific cases, and then appealed to the constitutional court.

${ }^{27}$ See discussion by Magalhães (2003). The lack of docket control avoids the limited ability to observe judicial policy preferences in assessing the decisions of a court with substantial discretionary jurisdiction (see Kastellec \& Lax 2008).
} 
block, the main party negotiates the distribution with minor parties, leaving the last judge to be neutral (to party affiliation). ${ }^{28}$

Previous results ${ }^{29}$ show that:

1. The higher the proportion of judges within the court that are affiliated with the party or parties that support a piece of legislation, the lower the probability that the court will declare the legislation unconstitutional.

2. Declarations of unconstitutionality are more likely when the legislation is supported by a large majority in the parliament, the proposed explanation being that a declaration of unconstitutionality will be more easily solved by the parliament.

3. There is a high correlation between party affiliation and voting, with respect to preventive review.

4. The court is substantially and increasingly polarized.

5. Judges appointed by the same party or belonging to the same block (left-right) exhibit above-average interagreement scores.

6. Being a career magistrate does not seem to increase independence in the manner constitutional judges vote.

7. Election or appointment seem to be irrelevant for predicting voting.

\section{The Data And Results}

Our article adds to previous work by testing party conformity and by making use of new data recorded in 2007 . We also test the effect of the 1997 reform on the behavior of constitutional judges (the change of tenure regime in the court from two renewable terms of six years to one nonrenewable term of nine years). We coded the entire data set of preventive constitutional cases from 1983 to 2007 initiated by the president. This data set was obtained by inspection of the court decisions, which are publicly available.

\footnotetext{
${ }^{28}$ As a consequence of this deal, we expect the average court to have six left-wing judges (zero to two communists, four to six socialists) and six right-wing judges (zero to two Christian Democrats, four to six conservatives). Details of this informal agreement are explained by de Araújo (1997) (in Portuguese).

${ }^{99}$ Magalhães and de Araújo (1998), de Araújo and Magalhães (2000) (both in Portuguese), and Magalhāes (1998, 2003).
} 
Table 1: Characteristics of Portuguese Constitutional Court Judges, 1985-2007

\begin{tabular}{lccccc}
\hline & $\begin{array}{c}\text { Conservatives } \\
(\text { Right })\end{array}$ & $\begin{array}{c}\text { Socialists } \\
\text { (Left) }\end{array}$ & $\begin{array}{c}\text { Communists } \\
(\text { Left })\end{array}$ & $\begin{array}{c}\text { Christian } \\
\text { Democrats } \\
\text { (Right) }\end{array}$ & Neutral \\
\hline Judges & 13 & 13 & 3 & 3 & 3 \\
Appointed & 3 & 2 & 2 & 1 & 3 \\
Elected & 10 & 12 & 2 & 3 & 0 \\
Career magistrate & 7 & 3 & 2 & 2 & 3 \\
Nonmagistrate & 6 & 10 & 1 & 1 & 0 \\
Pre-1997 reform & 8 & 8 & 3 & 3 & 2 \\
Post-1997 reform & 8 & 8 & 1 & 1 & 2 \\
Female & 2 & 3 & 0 & 0 & 0 \\
Male & 11 & 10 & 3 & 3 & 3 \\
\hline
\end{tabular}

Note: Some judges are counted more than once because they switched from elected to appointed (three judges) or were in court before and after the 1997 reform (nine judges).

Source: Portuguese constitutional court, 1985-2007.

Table 1 describes the characteristics of the judges and additional detail is presented in the working paper version of the article. ${ }^{30}$ Most of the constitutional court decisions are from 1985 to 1995 and 2002 to 2005, when there was a conservative majority in the parliament and a socialist president. Of a total of 270 decisions: 6 are from before 1985, 193 from the period 1985 to 1995, 25 from the period 1995 to 2002, 24 from 2002 to 2005, and 22 from 2005 to 2007 . We considered the number and nature of individual votes taken over each decision with regard to preventive constitutional review. Therefore, our methodology differs from the previous literature since the unit of analysis is each individual vote on each constitutional issue, and not each decision taken by the court in general. Each decision can include several votes with respect to different legal issues and questions, including willingness to review. ${ }^{31}$ Peer pressure in the court is evidenced by

\footnotetext{
${ }^{30}$ See Amaral-Garcia et al. (2008:Appendix tabs. A1-A5).

${ }^{31}$ Decisions concerning admission are also considered. We take the view that a vote against admission is a vote in favor of constitutionality of the law since it will not be subject to preventive judicial review.
} 
Table 2: Party Ideology and Judicial Votes on Constitutionality

\begin{tabular}{|c|c|c|c|c|}
\hline Party-N (\%) & $\begin{array}{l}\text { Judge Votes for } \\
\text { Constitutionality }\end{array}$ & $\begin{array}{l}\text { Judge Votes } \\
\text { Against } \\
\text { Constitutionality }\end{array}$ & Total & $\begin{array}{l}\text { Number } \\
\text { of Judges }\end{array}$ \\
\hline Right-wing parties & $1,096(79.1 \%)$ & $290(20.9 \%)$ & 1,386 & 16 \\
\hline Left-wing parties & $579(42.9 \%)$ & $771(57.1 \%)$ & 1,350 & 16 \\
\hline Neutral & $134(51.2 \%)$ & $128(48.8 \%)$ & 262 & 3 \\
\hline Total & 1,809 & 1,189 & 2,998 & \\
\hline
\end{tabular}

NoTt: Right-wing parties are conservatives and Christian Democrats; left-wing parties are socialists and communists.

Source: Individual judges' votes in 270 preventive review decisions, 2,998 total observations (entire data set), Portuguese constitutional court, 1985-2007.

Table 3: Party Ideology and Judicial Votes on Constitutionality Excluding Unanimous Decisions

\begin{tabular}{lrrrr}
\hline Party-N (\%) & $\begin{array}{c}\text { Judge Votes for } \\
\text { Constitutionality }\end{array}$ & $\begin{array}{c}\text { Judge Votes } \\
\text { Against } \\
\text { Constitutionality }\end{array}$ & Total & $\begin{array}{r}\text { Number } \\
\text { of Judges }\end{array}$ \\
\hline Right-wing parties & $835(85.1 \%)$ & $146(14.9 \%)$ & 981 & 16 \\
Left-wing parties & $340(35.2 \%)$ & $627(64.8 \%)$ & 967 & 16 \\
Neutral & $79(44.4 \%)$ & $99(55.6 \%)$ & 178 & 3 \\
Total & 1,254 & 872 & 2,126 & \\
\hline
\end{tabular}

NoTE: Right-wing parties are conservatives and Christian Democrats; left-wing parties are socialists and communists.

Source: Individual judges' votes in 186 preventive review decisions, 2,126 observations (entire data set excluding unanimous decisions), Portuguese constitutional court, 1985-2007.

unanimous votes, constituting 84 of 270 decisions. Unanimous decisions are disproportionately higher in the period $1985-1995 .{ }^{32}$

To begin describing the relation between party ideology and judicial votes on constitutional issues, consider Tables 2 and 3. Table 2 shows, as expected, that judges from right-wing parties are much more likely to vote in favor of constitutionality than are judges from left-wing parties. Almost 80 percent of right-wing votes were in favor of constitutionality, as compared to well under 50 percent of left-wing votes. These results are even more striking in Table 3, when unanimous decisions are excluded. More than 85 percent

32The political explanation is that one of the explicit goals of the conservative majority in the parliament in the period 1985-1995 was to undo constitutional rights. 
Table 4: Party in Power and Judicial Votes on Constitutionality

\begin{tabular}{|c|c|c|c|}
\hline Party-N $(\%)$ & $\begin{array}{l}\text { Judge Votes for } \\
\text { Constitutionality }\end{array}$ & $\begin{array}{c}\text { Judge Votes } \\
\text { Against } \\
\text { Constitutionality }\end{array}$ & Total \\
\hline A. Right-Wing Parties & 1,096 & 290 & 1,386 \\
\hline Conservatives in government & $883(78.8 \%)$ & $237(21.2 \%)$ & 1,120 \\
\hline Conservatives in opposition & $213(80.1 \%)$ & $53(19.9 \%)$ & 266 \\
\hline B. Left-Wing Parties & 579 & 771 & 1,350 \\
\hline Conservatives in government & $369(34.4 \%)$ & $704(65.6 \%)$ & 1,073 \\
\hline Conservatives in opposition & $210(75.8 \%)$ & $67(24.2 \%)$ & 277 \\
\hline
\end{tabular}

NoTE: Right-wing parties are conservatives and Christian Democrats; left-wing parties are socialists and communists.

SourCE: Individual judges' votes in 270 preventive review decisions, 2,736 observations (entire data set excluding votes by neutral judges), Portuguese constitutional court, $1985-2007$.

of right-wing votes were in favor of constitutionality as compared to 35 percent of left-wing votes. Therefore, we have evidence that (1) peer pressure within the court is important and restrains ideological bias and (2) ideological bias plays an important role, as evidenced by the fact that judges appointed by right-wing parties are much more prone to vote for constitutionality than judges appointed by left-wing parties; the neutral judges are somewhere in the middle. ${ }^{33}$

However, these results do not allow us to distinguish conformity due to judicial preferences (ideological bias) and straight political pressure (not necessarily active pressure). First, we propose a test of decomposing judicial behavior when the major party, the conservatives (center-right), is in government (from 1982 to 1995 and 2002 to 2005), and then in opposition (from 1995 to 2002 and since 2005). The results in Table 4 indicate that the vote by right-wing judges does not materially change, but the vote by leftwing judges seems to be sensitive to the party in power within government. Although the judges appointed by the parties on the right (conservatives and Christian Democrats) do not seem to be significantly affected by the fact that their party or ideological block is in power, the opposite holds true for the judges appointed by the parties on the left (socialists and communists). Therefore, our results suggest that judges appointed by the right exhibit ideological bias due to their preferences (to undo the 1976 constitutional

\footnotetext{
${ }^{33}$ Friedman (2005) discusses a similar balance between judicial ideology and intracourt interaction in the U.S. Supreme Court.
} 
Table 5: Party Ideology and Judicial Votes on Constitutionality Before and After the 1997 Reform

\begin{tabular}{lrrr}
\hline & & \multicolumn{2}{c}{ Judge Votes } \\
Party-N (\%) & $\begin{array}{c}\text { Judge Votes for } \\
\text { Constitutionality }\end{array}$ & $\begin{array}{c}\text { Against } \\
\text { Constitutionality }\end{array}$ & Total \\
\hline A. Right-Wing Parties & 1,096 & 290 & 1,386 \\
First and second courts (1983-March 1998) & $865(79.6 \%)$ & $221(20.4 \%)$ & 1,086 \\
Third and fourth courts (March 1998-2007) & $231(77.0 \%)$ & $69(23.0 \%)$ & 300 \\
B. Left-Wing Parties & 579 & 771 & 1,350 \\
First and second courts (1983-March 1998) & $392(37.9 \%)$ & $641(62.1 \%)$ & 1,033 \\
Third and fourth courts (March 1998-2007) & $187(59.0 \%)$ & $130(41.0 \%)$ & 317 \\
C. Neutral & 134 & 128 & 262 \\
First and second courts (1983-March 1998) & $97(46.4 \%)$ & $112(53.6 \%)$ & 209 \\
Third and fourth courts (March 1998-2007) & $37(69.8 \%)$ & $16(30.2 \%)$ & 53 \\
\hline
\end{tabular}

NoTE: Right-wing parties are conservatives and Christian Democrats; left-wing parties are socialists and communists.

Source: Individual judges' votes in 270 preventive review decisions, 2,998 observations (entire data set), Portuguese constitutional court, 1985-2007.

arrangement), while judges appointed by the left seem to be more sensitive to party politics (in or out of government). ${ }^{34}$

An initial sense of the impact of the 1997 reform (change of tenure regime) on judicial behavior emerges in Table 5. Unfortunately, the results are not promising. The apparent changes in behavior by left-wing judges are easily explained by the fact that the third and fourth courts (1998-2007) largely overlapped with a left-wing majority in the legislature. Regression analysis reported later in the article confirms that the changes in 1997 had no substantial impact on the independence of the court. That might be due to (1) path dependence (i.e., it is too early to test the far-reaching consequences of the 1997 reform), (2) adverse selection problems (it is unclear if the 1997 reform altered the type of individuals willing to serve for nine years in the court with no possibility of reappointment), or (3) reinforcement of postterm prospects (judges' concern about what happens after they leave the court).

\footnotetext{
${ }^{34}$ The explanation that legislation approved by a left-wing parliamentary majority is of a different nature than legislation approved by a right-wing parliamentary majority does not seem plausible because the legislation reviewed by the court is filtered by the president, who was center-left from 1982 to 2006. In fact, if one takes a public choice perspective that a center-left president is more likely to favor center-left legislation, then the legislation reviewed by the court when a left-wing majority prevails should be clearly more unconstitutional than when a right-wing majority prevails.
} 
Table 6: Judicial Background and Judicial Votes on Constitutionality

\begin{tabular}{|c|c|c|c|c|}
\hline Party-N (\%) & $\begin{array}{l}\text { Number } \\
\text { of Judges }\end{array}$ & $\begin{array}{l}\text { Judge Votes for } \\
\text { Constitutionality }\end{array}$ & $\begin{array}{c}\text { Judge Votes } \\
\text { Against } \\
\text { Constitutionality }\end{array}$ & Total \\
\hline A. Right-Wing Parties & & 1,096 & 290 & 1,386 \\
\hline Appointed judges & 4 & $151(77.1 \%)$ & $45(22.9 \%)$ & 196 \\
\hline Elected judges & 13 & $945(79.4 \%)$ & $245(20.6 \%)$ & 1,190 \\
\hline Magistrates & 9 & $556(80.0 \%)$ & $139(20.0 \%)$ & 695 \\
\hline Nonmagistrates & 7 & $540(78.1 \%)$ & $151(21.9 \%)$ & 691 \\
\hline B. Left-Wing Parties & & 579 & 771 & 1,350 \\
\hline Appointed judges & 4 & $94(42.2 \%)$ & $129(57.8 \%)$ & 223 \\
\hline Elected judges & 14 & $485(43.0 \%)$ & $642(57.0 \%)$ & 1,127 \\
\hline Magistrates & 5 & $176(38.6 \%)$ & $280(61.4 \%)$ & 456 \\
\hline Nonmagistrates & 11 & $403(45.1 \%)$ & $491 \quad(54.9 \%)$ & 894 \\
\hline C. Neutral & & 134 & 128 & 262 \\
\hline Appointed judges & 3 & $134(51.2 \%)$ & $128(48.8 \%)$ & 262 \\
\hline Elected judges & 0 & $0(-)$ & $0(-)$ & 0 \\
\hline Magistrates & 3 & $134(51.2 \%)$ & $128(48.8 \%)$ & 262 \\
\hline Nonmagistrates & 0 & $0(-)$ & $0(-)$ & 0 \\
\hline
\end{tabular}

NoTE: Right-wing parties are conservative and Christian Democrats; left-wing parties are socialists and communists.

SOURCE: Individual judges' votes in 270 preventive review decisions, 2,998 observations (entire data set), Portuguese constitutional court, 1985-2007.

Finally, we assess the voting pattern based on whether a judge is selected by appointment, rather than by parliamentary election, and if having a previous career as a magistrate is associated with differences among judges. Table 6 shows the results. The neutral judge (the 13th judge in each of the four courts) is an appointed magistrate. No significant difference exists between the behavior of appointed and elected judges on one hand, or between magistrates and nonmagistrates on the other hand.

Consequently, the results obtained thus far from decomposing and analyzing the data set are:

1. There seems to be an association between being affiliated with a right-wing party (conservatives and Christian Democrats) and voting for constitutionality; conversely, there seems to be a correlation between being affiliated with a left-wing party (socialists and communists) and voting for unconstitutionality.

2. When the left is in power (the right in opposition), the judges affiliated with the left-wing parties (socialists and communists) are more likely to vote for constitutionality; however, such an effect does not take place on the right. 
3. The 1997 reform had no apparent strong effect on voting patterns.

4. Appointment versus election, and being a career magistrate, are not associated with a significant impact on voting patterns.

\section{Regression Analysis}

We developed a set of regressions to confirm the above preliminary results, and to further investigate the determinants of judicial behavior in the Portuguese constitutional court. We start by constructing two dependent variables:

1. A vote for the constitutionality of the law: the dependent variable takes the value of 1 if the judge's vote is for the constitutionality of a law; 0 otherwise.

2. A vote ACCORDING TO PARTY InTERESTs: the dependent variable takes the value of 1 if the judge's vote mimics the vote of the party in the legislature; 0 otherwise.

The explanatory variables include:

1. Political variables (used to assess the extent to which they influence judicial behavior in the constitutional court):

a. Political affiliation: constitutional judges are grouped by left (socialists and communists) and right (conservatives and Christian Democrats) to avoid limitations due to the fact that the two smallest parties have lost their judges. ${ }^{35}$

b. Party in Government: has a value equal to 1 if the judge was affiliated with the ideological block in government; 0 otherwise.

c. Appointment versus election: has a value equal to 1 if the judge has been elected; 0 otherwise.

d. Magistrate: has a value equal to 1 if the judge is a career magistrate; 0 otherwise.

e. 1997 REFORM: has a value equal to 1 if the individual vote occurred in the first or second courts; 0 otherwise. ${ }^{36}$

\footnotetext{
${ }^{35}$ See discussion in note 28 and characterization of data set in Table 1. The fourth court, for example, had no judges from the smaller parties.

${ }^{36}$ Recall that enhancing independence was one of the publicized reasons for the reform.
} 
f. Peer Pressure: has a value equal to 1 if the judges voted by unanimity against constitutionality; 0 otherwise.

g. Media Proxy variables: has a value equal to 2 if a case received a lot of attention (i.e., press coverage well before and well after the court decision) from the main national newspapers; has a value equal to 1 if a case received some attention (i.e., some press coverage the day or days before the vote); and has a value equal to 0 if a case was not reported in the media before the vote took place.

2. Personal attributes:

a. GENDER: has a value equal to 1 if the judge is male, and 0 if the judge is female.

b. AGE: the age of the judge at the time of appointment.

3. Specific laws:
a. LABOR LAwS: has a value equal to 1 if the law is related to the regulation of labor (broadly defined to include laws that deregu- late labor relations); 0 otherwise. ${ }^{37}$
b. Social POlicy Laws: has a value equal to 1 if the law is related to significant changes in social policy (e.g., health and education); 0 otherwise..$^{38}$

\section{Economic context:}

a. The GDP per capita of the year the decision took place.

b. The UNEMPLOYMENT rate in the year the vote took place.

c. The INFLATION rate in the year the vote took place.

Given the inclusion of a constant, we use the neutral judge as the reference category in the regression analysis using VOTING FOR CONSTITUTIONALITY as the dependent variable. Therefore, the coefficients of party affiliation should be interpreted with respect to the neutral judge. Finally, several fixed effects were considered per judge and per court. Usually with these types of regressions, we should consider the signal and not place too much emphasis on the

\footnotetext{
${ }^{37}$ Given the ideological bias of the Portuguese Constitution, the regulation of labor and employment is very rigid and has been the object of legislative reforms by several governments. These legislative reforms usually have serious constitutional problems.

${ }^{38}$ The Portuguese Constitution prescribes public health and education systems with free access. Serious budgetary problems and lack of efficiency have led different governments to introduce important changes in these systems that usually end up under judicial review by the constitutional court.
} 
magnitude of the estimated coefficients. In other words, we do not assess quantitatively the marginal impact of each explanatory variable on the probability of a judge voting for constitutionality, or according to party interests; instead, it is assessed qualitatively.

Tables 7 and 8 summarize the main results (further regression analysis can be found in the working paper version) ${ }^{39}$ We present the estimated logit models using Stata (version 10) with and without fixed effects per court and per judge. Due to the nonindependence of the votes within cases and within decisions (recall that each case might have more than one decision), we further estimated the logit models correcting for the nonindependence, in particular, initially using cases as the primary sampling unit (PSU) and then decisions. This was also done with clustering on case initially, and then on decision.

With respect to vOTING FOR CONSTITUTIONALITY, the regression analysis largely confirms the preliminary analysis of the data set. First, the influence of political variables matters. Being a left-wing judge decreases the probability of voting for constitutionality, whereas the coefficient for rightwing judges is statistically significant in fewer models and is unstable in direction across the models (recall that a baseline is provided by the neutral judge and note that the coefficient for the right-wing judges is always smaller than that for the left-wing judges). The judge being associated with the party in government increases the probability of voting for constitutionality. Second, specific laws seem to affect the way judges vote (labor laws have a consistent, statistically significant negative marginal impact, whereas social policy laws seem to have a positive marginal impact ${ }^{40}$ ). Third, economic context variables, as well as age, gender, magistrate, election versus appointment, and the media, do not have a robust pattern of statistical significance. Finally, the 1997 reform has no statistically significant impact on patterns of voting for constitutionality.

With respect to vOTING ACCORDING TO PARTY INTERESTs, the regression analysis in Table 8 further confirms the importance of peer pressure and party politics in the court. First, being a left-wing judge increases the probability of voting according to party interests (the opposite is true for a right-wing judge since neutral judges were excluded). The judge being associated with the party in government increases the probability of judges

\footnotetext{
${ }^{39}$ Amaral-Garcia et al. (2008).

${ }^{40}$ See notes 37 and 38 for details.
} 


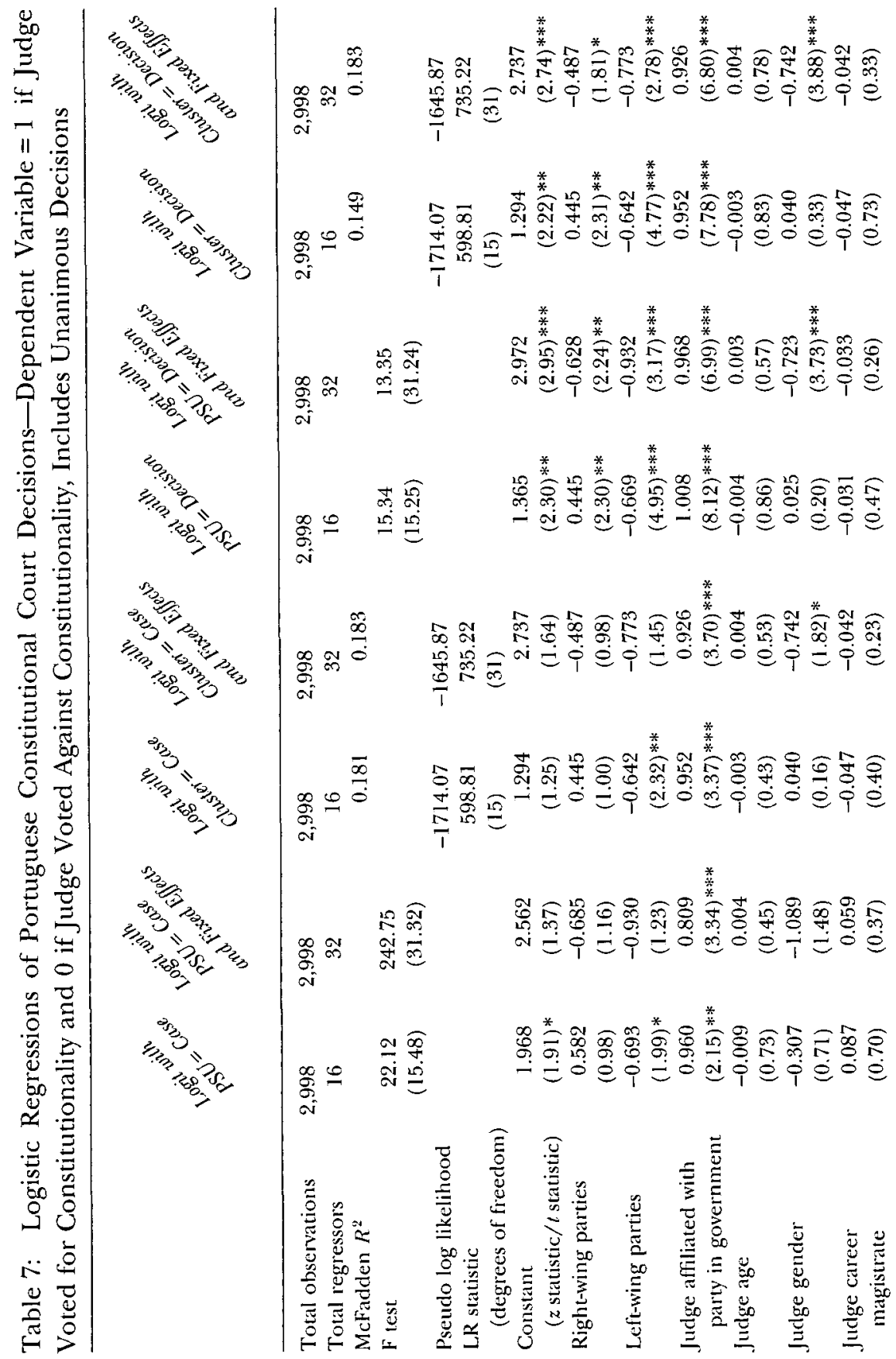




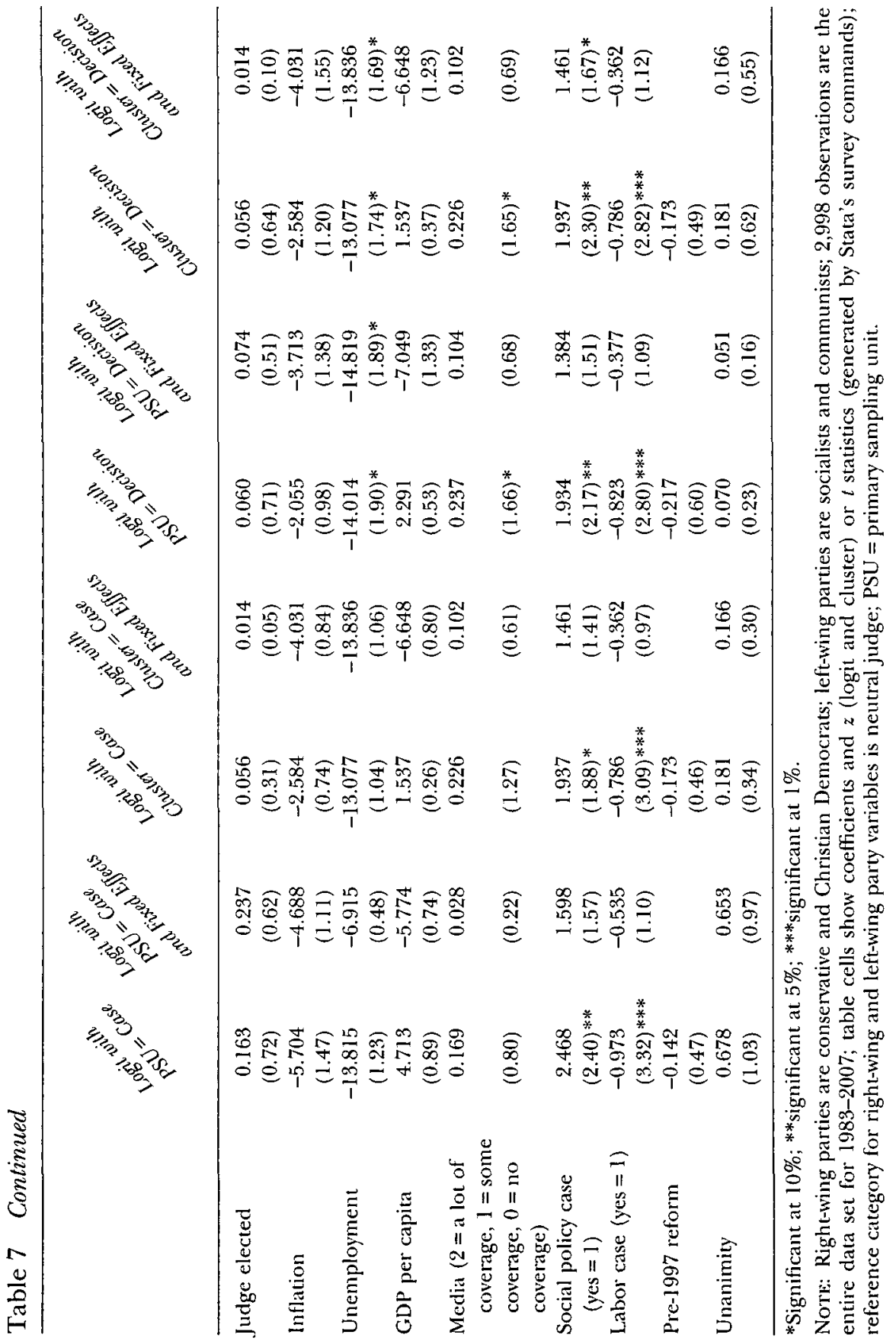




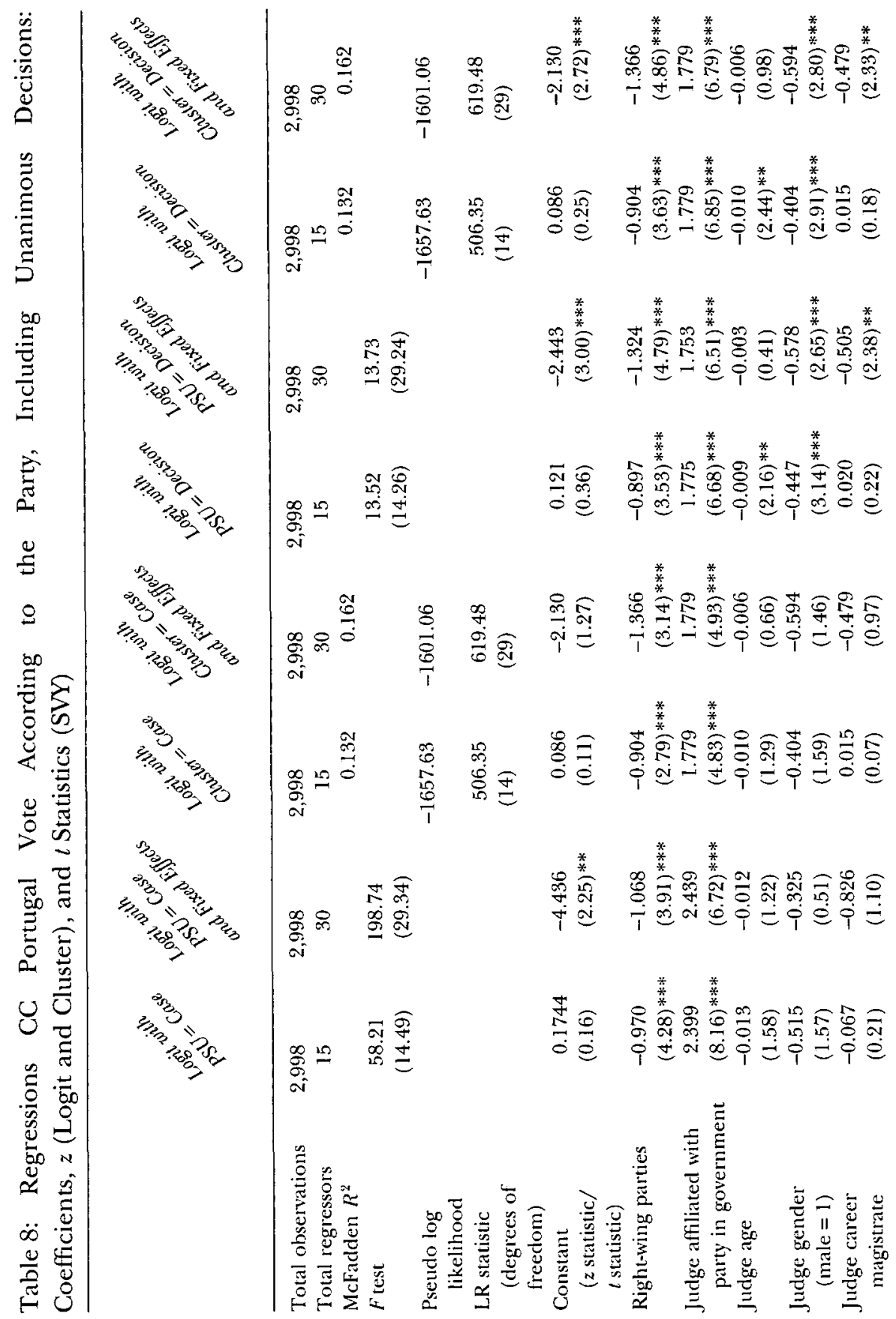




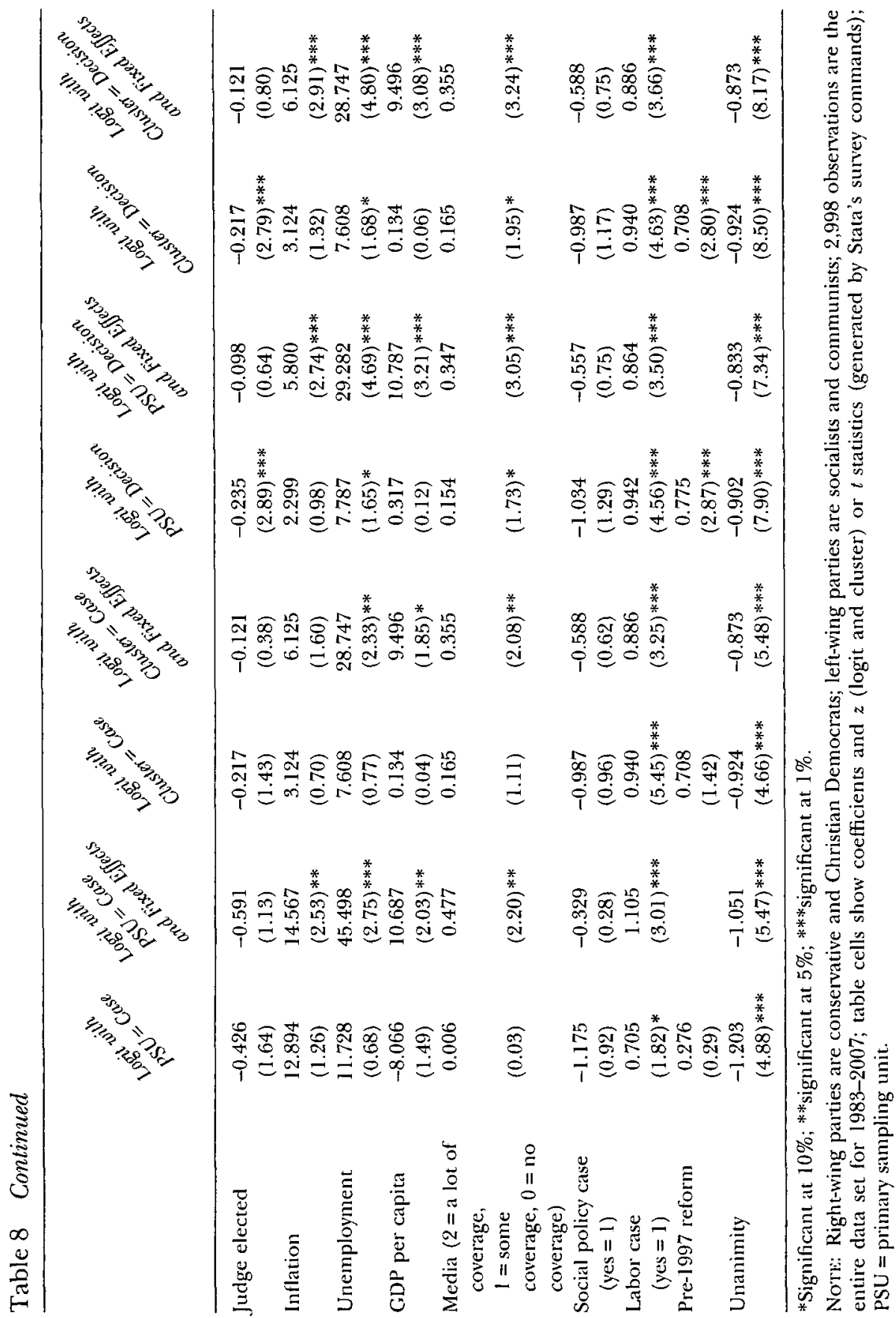


voting according to party interests. Second, specific laws affect the way judges vote (labor laws have a consistent statistically significant positive marginal impact, whereas social policy laws seem to have a negative marginal impact, although not statistically significant). Third, as stated earlier, economic context variables, as well as age, gender, magistrate, elected, and the media, are not consistently statistically significant. The 1997 reform has no robust statistically significant impact on patterns of voting according to party interests (although the coefficient is, unsurprisingly, always positive). However, unanimity, as expected, significantly reduces the likelihood of voting according to party interests.

The influence of political variables in Tables 7 and 8 is now examined in more detail. They confirm that constitutional judges are politicized when voting. Nevertheless, the patterns are dissimilar when comparing the leftwing to the right-wing. For example, constitutional judges affiliated with the left (socialists and communists) have a marginal effect that is consistently negative (i.e., more likely to vote against constitutionality), whereas the right (conservatives and Christian Democrats), once the nonindependence of the votes is corrected, or fixed effects are taken into consideration, has a marginal effect that is not statistically significant. This is further confirmed by the fact that the left is more likely to vote according to party interests than is the right.

The party in power is statistically significant, and has an expected positive marginal effect (the interests of the judges seem to be more aligned with party affiliation when the party or ideological blocks are in power). Neither being a career magistrate nor an appointed judge have any statistical marginal effect on voting, which confirms our preliminary results. The marginal effect of the 1997 reform does not seem to be a very significant variable since nothing major has changed since then, which also confirms our preliminary results (although the sign of the coefficient concurs with more independence).

The effects of peer pressure are important, evidenced by the fact that around 30 percent of the decisions of the constitutional court have been unanimous ( 84 out of 270 ). This is confirmed by the impact of voting according to party interests.

From our study, the econometric results suggest that politics, as well as peer pressure, are relevant in the Portuguese constitutional court. Furthermore, these results suggest that politics matter at two different levels. Constitutional judges have their preferences aligned with the parties that appoint them, and naturally they vote frequently in the same manner (the 
result seems to be stronger for the left than for the right). However, the robustness of the marginal effect of the party in power indicates some opportunistic behavior by political parties (party alignment is stronger when the interests of the party are more significant).

\section{Conclusions}

This article presents an empirical study of the Portuguese constitutional court with respect to judicial independence and judicial preventive constitutional review. We analyzed individual votes by constitutional judges from 1983 to 2007.

Our results indicate that party politics plays an important role in the Portuguese constitutional court. However, additional variables matter. The empirical evidence also suggests that peer pressure is very relevant for unanimous voting, with around 30 percent of the decisions concerning preventive review being unanimous.

We have shown that there is a strong association between being affiliated with a left-wing party (socialists and communists) and voting for unconstitutionality, whereas the association between the right-wing parties (conservatives and Christian Democrats) and voting for constitutionality is weak. These results are confirmed when we look at voting according to party interests, legislation that has also been endorsed by the party with which the constitutional judge is supposed to be affiliated.

The government being in power matching the constitutional judge's party seems to play an important role in both a judge's decision to vote for constitutionality, and in his or her vote according to party interests. Our interpretation is that not only does party affiliation matter in terms of aligned preferences, but some opportunism takes place. That is, party politics is more important when the stakes are higher. Therefore, we conclude that party conformity takes place frequently due to judicial preferences (albeit, ideologically biased), and occasionally due to direct political pressure (not necessarily active pressure).

We also discovered that some other controlled variables are relevant in predicting judicial behavior. Therefore, party politics and peer pressure are not the only relevant dimensions in the Portuguese constitutional court. For example, specific laws on labor regulation, or on social policy, seem to have a marginal impact on judicial behavior (albeit with different levels of robustness). It is also clear from the empirical results that the 1997 reform had no 
statistically significant effect on the voting behavior of judges. Nevertheless, data from future years will be needed to settle this question in a more satisfactory way.

\section{REFERENCES}

Amaral, M. L. (2005) "Problemas da Judicial Review em Portugal," Themis 6.

Amaral-Garcia, S. A., N. Garoupa, \& V. Grembi (2008) Judicial Independence and Party Politics in the Kelsenian Constitutional Courts: The Case of Portugal. SSRN Working Paper.

Ashenfelter, O., T. Eisenberg, \& S. J. Schwab (1995) "Politics and the Judiciary: The Influence of Judicial Background on Case Outcomes," $24 \mathrm{~J}$. of Legal Studies 257.

Baum, L. (1994) "What Judges Want: Judges' Goals and Judicial Behavior," 47 Political Research Q. 749.

Bell, J. (1988) "Principles and Methods of Judicial Selection in France," 61 Southern California Law Rev. 1757.

Cooter, R. (1992) "The Minimax Constitution as Democracy," 12 International Rey. of Law $\mathcal{E}$ Economics 292.

Costa Lobo, M. (2006) "Short-Term Determinants in a Young Democracy: Leader Effects in Portugal in the 2002 Legislative Elections," 25 Electoral Studies 270.

Davis, M. H. (1986) "The Law/Politics Distinction, the French Conseil Constitutionnel and the US Supreme Court," 34 American J. of Comparative Law 45.

de Araújo, A. (1997) O Tribunal Constitucional (1989-1996), Um Estudo de Comportamento Judicial. Coimbra: Editora.

de Araújo, A., \& P. C. Magalhães (2000) "A Justiça Constitucional: Uma Instituição Contra as Maiorias," 35 Análise Social 207.

Easterbrook, F. H. (1990) "What's So Special About Judges?" 61 Univ. of Colorado Lazu Rev. 773.

Epstein, R. (1990) "The Independence of Judges: The Uses and Limitations of Public Choice," Brigham Young Univ. Law Rev. 827.

Fiorino, N., F. Padovano, \& G. Sgarra (2007) "The Determinants of Judicial Independence: Evidence from the Italian Constitutional Court (1956-2002)," $163 \mathrm{~J}$. of Institutional $\mathcal{E}$ Theoretical Economics 683.

Friedman, B. (2005) "The Politics of Judicial Review," 84 Texas Law Reu. 256.

George, T. E., \& L. Epstein (1992) "On the Nature of Supreme Court Decision Making," 86 American Political Science Rev. 323.

Ginsburg, T. (2002) "Economic Analysis and Design of Constitutional Courts," 3 Theoretical Inquiries in Law.

—_ (2003) Judicial Review in New Democracies: Constitutional Courts in Asian Cases. Cambridge: Cambridge Univ. Press.

Goldey, D. (1983) "Elections and Consolidation of Portuguese Democracy," 2 Electoral Studies 229.

Guthrie, C., J. J. Rachlinski, \& A. J. Wistrich (forthcoming) "Blinking on the Bench: How Judges Decide Cases," Cormell Law Rev. 
Harvey, A., \& B. Friedman (2006) "Pulling Punches: Congressional Constraints on the Supreme Court's Constitutional Rulings, 1987-2000," 31 Legislative Studies Q.553.

Kastellec, J. P., \& J. R. Lax (2008) "Case Selection and the Study of Judicial Politics," 5 J. of Empirical Legal Siudies 407.

Kelsen, H. (1942) "Judicial Review of Legislation: A Comparative Study of the Austrian and the American Constitution," 4 J. of Politics 183.

Kommers, D. (1994) "The Federal Constitution Court in the German Political System," 26 Comparative Political Studies 470.

Landes, W., \& R. Posner (1975) "The Independent Judiciary in an Interest-Group Perspective," $18 \mathrm{~J}$. of Law $\mathcal{E}$ Economics 875.

Lax, J. R., \& C. M. Cameron (2007) "Bargaining and Opinion Assignment on the US Supreme Court," $23 \mathrm{~J}$. of Law, Economics $\mathcal{E}$ ' Organization 276.

Lutz, D. (1994) "Toward a Theory of Constitutional Amendment," 88 American Political Science Rev. 355.

Magalhães, P. C. (1998) "Judicial Behavior in Constitutional Courts: The Case of Portugal," paper presented at the 1998 Annual Conference of the Scientific Study of Judicial Politics. Michigare State Univ.

- (2003) "Judicial Decision-Making in the Iberian Constitutional Courts: Policy Preferences and Institutional Constraints," paper presented at the Colloquium on Law, Economics and Politics. New York Univ.

Magalhães, P. C., \& A. de Araújo (1998) "A Justiça Constitucional entre o Direito e a Política: o Comportamento Judicial no Tribunal Constitucional Português," 33 Análise Social 7.

Magone, J. (2005) "Portugal," 44 European J. of Political Research 1158.

McCubbins, M. D., \& D. B. Rodriguez (2006) "The Judiciary and the Role of Law: A Positive Political Theory Perspective," in B. Weingast \& D. Wittman, eds., The Handbook of Political Economy. Oxford: Oxford Univ. Press.

Posner, R. (1993) "What Do Judges and Justices Maximize? (The Same Thing Everybody Else)," 3 Supreme Court Economic Rev. 1.

- (2005) "Judicial Behavior and Performance: An Economic Approach," 32 Florida State Univ. Law Rev. 1259.

Ramos, F. (2006) "The Establishment of Constitutional Courts: A Study of 128 Democratic Constitutions," 2 Rev. of Law E E Economics 103.

Ramseyer, J. M. (1994) “The Puzzling (In)dependence of Courts," 23 J. of Legal Studies 721.

Ramseyer, J. M., \& E. B. Rasmusen (2003) Measuring Judicial Independence: The Political Economy of Judging in Japan. Chicago, IL: Univ. of Chicago Press.

__ (2006) "The Case for Managed Judges: Learning from Japan After the Political Upheaval of 1993," 154 Univ. of Pennsylvania Law Rev. 1879.

Schauer, F. (2000) "Incentives, Reputation, and the Inglorious Determinants of Judicial Behavior," 68 Univ. of Cincinnati Law Rev. 615.

Vanberg, G. (1998) "Abstract Judicial Review, Legislative Bargaining and Policy Compromise," $10 \mathrm{~J}$. of Theoretical Politics 299. 